\title{
Molecular characterization of methicillin resistant Staph. aureus from poultry farms in Kano State, Nigeria
}

\author{
Bala H. K. ${ }^{1}$, Igwe J. C. ${ }^{2}$, Olayinka B. O. ${ }^{2}$, Olonitola O. S. ${ }^{2}$ and Onaolapo J. A. ${ }^{1 *}$ \\ 1Department of Pharmaceutics and Pharmaceutical Microbiology, Ahmadu Bello University, Zaria, Nigeria. \\ 2Department of Medical Biotechnology, National Biotechnology Development Agency, Abuja, Nigeria. \\ ${ }^{*}$ Corresponding author. Email: jaonaolapo@gmail.com
}

Copyright (c) 2016 Bala et al. This article remains permanently open access under the terms of the Creative Commons Attribution License 4.0, which permits unrestricted use, distribution, and reproduction in any medium, provided the original work is properly cited.

Received 18th May, 2016; Accepted 10th September, 2016

\begin{abstract}
There is presently an increased rate of resistance by methicillin resistant Staph. aureus against commonly prescribed antibiotics for Staph aureus infection. This strain of Staph. aureus is not only a problem in clinical sector but also in livestock disease treatment and management as transferability of this resistant gene in zoonotic outbreak might be possible. This study was set out to evaluate the incidence of methicillin resistant Staph. aureus from poultry farms birds and the farm workers, and also to evaluate the likelihood of cross-infection between the birds and the farm workers in Kano State, Nigeria. Samples were collected using standard microbiological techniques. Antibiotic susceptibility was also carried out using disc diffusion method while genes that influence methicillin resistant were evaluated using PCR method. The results showed that out of the 1260 samples collected, 98 isolates were confirmed to be Staph. aureus. The antibiotics susceptibility test results showed that $30.6 \%(30)$ of the Staph. aureus isolates were resistant to cefoxitin (a phenotypic test for methicillin resistant) while 69.4\% (68) were susceptible. The methicillin resistant isolates were observed to exhibit (100\%) resistant to Ampicillin and Amoxicillin, $93.3 \%$ to Oxytetracycline, $90 \%$ to Chloramphenicol, $80 \%$ to Erythromycin, $76.7 \%$ to Oxacillin, $63.3 \%$ to Trimethroprim/Sulphamethozaxole, $30 \%$ to Ciprofloxacin and $26.7 \%$ to Gentamicin. The result also showed that $83.3 \%(25)$ of the isolates had multiple antibiotic resistance index (MARI) of $>0.3$ and were also multidrug resistant (MDR) while $16.7 \%$ had MARI $\leq 0.3$. The molecular analysis showed that all the isolates were Staph. aureus of $800 \mathrm{bp}, 66.7 \%$ of the MDR isolates harbored MecA gene (162bp), while $33.3 \%$ had MecA of $500 \mathrm{bp}$. Further analysis showed that 3 of the 7 housekeeping genes ( $p t a, g m k$ and yqil) were also present in the MDR isolates at 43.3, 20 and $16.7 \%$ respectively while $10 \%$ express spa typing. The results also showed that there is a correlation between phenotypic cefoxitin resistance and carriage of $M e c A$ gene.
\end{abstract}

Key words: Methicillin resistance, poultry farms, Staph. Aureus.

\section{INTRODUCTION}

In poultry management, antibiotics such as $\beta$-lactams are often used in animal food production for growth promotion and routine disease prevention without prescription or control measures. This encourage drug resistance superbug such as methicillin resistant Staph. aureus (MRSA), which is now a major emerging public health problem (Klevens et al., 2007). With increase in population density within a particular geographical location, the incidence of both communities associated and hospital associated MRSA has been observed to increase with time, regardless of hospital size and control measures due to drug abuse and zoonotic transfer of resistance gene through horizontal gene transfer (Adelisa et al.,1992; Igwe et al., 2013). In 2005, the standardized incidence rate of invasive MRSA in USA hospitals was 31.8 per 100000 patients (interval estimate, 24.4-35.2) with standardized mortality rate of 6.3 per 100000 (interval estimate, 3.3-7.5) (Klevens et al., 2007). This has indeed influenced high mortality and morbidity rates especially in immunocompromised patients and among persons of 65 years and older, as MRSA accounts for the most frequent cause of skin and soft tissue infections in USA (Sara et al., 2003; Moranet al., 2006; Klevens et al., 2007). Most community associated MRSA have been 
reported to show susceptibility to non- $\beta$-lactam antimicrobial agents; carried staphylococcal cassette chromosome type IV, and frequently encoded the dermonecrotic cytotoxin known as Panton-Valentine leukocidin (Naimi et al., 2003; Ma et al., 2002). The transfer of nosocomial infections of MRSA majorly occur from patients who has recently visited the hospital or nursing home residence (Naimi et al., 2003). Vancomycin resistant Staph. aureus isolates that habour resistance genes against Glycopeptides especially Vancomycin with high MIC range have been reported (George et al., 2004). Glycopeptides especially Vancomycin are antibiotics of choice for the treatment of MRSA infection. Surveys conducted by the National Antimicrobial Resistance Monitoring System (NARMS) indicate that retail meat and poultry products are frequently contaminated with multidrug-resistant Campylobacter species, Salmonella species, Enterococcus species, and Escherichia coli (FDA, 2007). This study therefore evaluates the pathogenicity of MRSA in poultry farms in Kano State, Nigeria due to lack of information in this area.

\section{METHODOLOGY}

\section{Sample Collection}

From the 3 geopolitical zones in Kano State, 4 farms each were randomly selected. Fifty (50) samples each from the chicken cloacae and nostril were aseptically collected. While 5 samples were collected from the poultry farm workers. A total of 1260 poultry chicken samples (consisting of 600 cloacae samples, 600 nostril samples and 60 samples from the poultry farm workers) were collected aseptically [using the method described by Adeyeye and Adewale (2013)] into a clean sterile universal bottle (Agary Pharmaceutical LTD, China) from the 12 poultry farms in Kano State and transported on an ice park to the laboratory for bacteriological examination.

\section{Staph. Species Identification, Isolation and Microscopy}

Collected samples were suspended in sterile normal saline which was prepared according to Cheesbrough (2000), and incubated for $24 \mathrm{hrs}$ at $37^{\circ} \mathrm{C}$ (National Appliance Co. Ltd, Oregon, USA: model 1630, 240V and $2340 \mathrm{~W}$ ), and there after inoculated on the surface of sterile nutrient agar (NA) for further 18 hrs incubation period at $37^{\circ} \mathrm{C}$. Gram staining and microscopy (Wild Heerbrugg M11, Switzerland) were also carried out to identify Gram positive organisms according to Cheesbrough (2000) while further morphological characteristics of Staph. aureus on Mannitol salt agar was also used to differentiate Staph. aureus from other microorganisms.
Biochemical Test for the Identification of Staph.
aureus

The following conventional biochemical tests; catalase, coagulase and deoxyribonuclease (DNase) tests as described by Cheesbrough (2002) were also adopted to distinguish Staph. aureus from other forms of Staph. spp. Further confirmatory tests for Staph. aureus i.e. STAPH Agglutination kit (Oxoid, UK) and Microgen STAPH kit (Microgene, UK) using manufacturers protocol were used to confirm the presumptive isolates to be Staph. aureus.

\section{Antibiotic Susceptibility Test, Multiple Antibiotic Resistance Index (MARI) Evaluation, and Classification of Drug Resistance}

The susceptibility profiles of the identified Staph. aureus was tested against Cefoxitin, since the toxicity associated with methicillin as restricted its use in Hospitals. Also the ability of cefoxitin to induce $m e c A$ protein, heteroresistance, long shelf life during storage and reproducibility of test in research has made it use better than oxacillin/methicillin (CLSI, 2014). Isolates that showed resistance to Cefoxitin were also evaluated for resistance against other antibiotics such as Sulphamethoxazole/Trimetophrim $(30 \mu \mathrm{g})$, Vancomycin $(5 \mu \mathrm{g})$, Erythromycin $(15 \mu \mathrm{g})$, Ciprofloxacin $(30 \mu \mathrm{g})$, Chloramphenicol $(10 \mu \mathrm{g})$, Oxacillin $(1 \mu \mathrm{g})$, Gentamicin $(10 \mu \mathrm{g})$ Ampicillin $(10 \mu \mathrm{g})$, Oxytetracycline $(30 \mu \mathrm{g})$, Augumentin $(30 \mu \mathrm{g})$ using disc diffusion method as described by Cheesbrough (2002) and the corresponding results interpreted according to CLSI (2014). The multiple antibiotic resistant (MAR) index was determined for each isolates. This is defined as the number of antibiotics to which the organism is resistant to, divided by the total number of antibiotics tested (Paul et al., 1997) while classification of drug resistance was determined according to the method described by Magiorakos et al. (2012). Multidrug resistance (MDR) is classified as nonsusceptible to $\geq 1$ agent in $\geq 3$ antimicrobial categories, extensive drug resistance (XDR) as non-susceptible to $\geq 1$ agent in all but $\geq 2$ categories, pandrug-resistance (PDR): non-susceptible to all antimicrobial agents listed. PDR was not considered because not all the antibiotics contained in the proposal of Magiorakos et al., (2012) were used in this study.

Molecular Analysis of Antibiotic Resistant and Pathogenic Genes Among Staph. aureus Isolated from Poultry Farms in Zaria, Nigeria

\section{DNA Extraction}

DNA extraction was carried out using Zymo research fungal/bacteria DNA miniprep ${ }^{\mathrm{TM}} \mathrm{kit}$ protocol with catalog number D6005 (Inqaba, South Africa). The extracted 
Table 1. Primers for Molecular Characterization of Antibiotic Resistant and Pathogenic Genes Among Staph. aureus Isolated from Poultry Farms in Zaria, Nigeria.

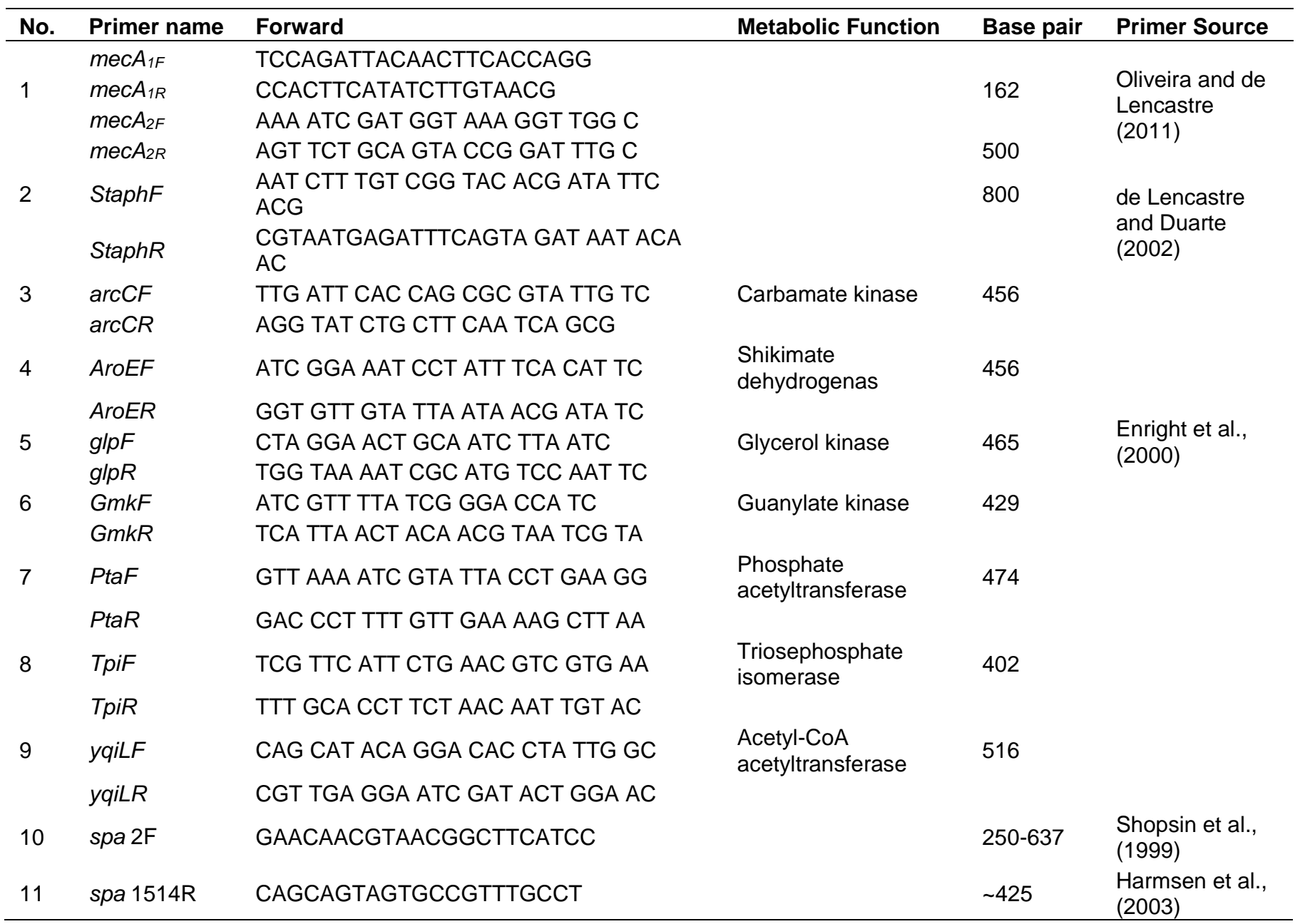

DNAs were run on $1 \%$ agarose gel electrophoresis (Schwarz/Mann, England) to confirm that the DNA was actually extracted while the purity of the extracted DNA was quantified using a Nano Drop Thermo machine (Eppendorf, UK).

\section{Polymerase Chain Reaction}

PCR was carried out using a cocktail mix of $3.5 \mu \mathrm{l}$ of $2 \mathrm{X}$ master mix from Promega, $0.5 \mu \mathrm{l}$ of $5 \mathrm{pMol}$ forward primer, $5 \mathrm{pMol}$ reverse primer, $3 \mu \mathrm{l}$ of $25 \mathrm{ng} / \mu \mathrm{l}$ of the extracted DNA and $2.5 \mu$ l nuclease free water to form a $10 \mu \mathrm{l} \mathrm{PCR}$ cocktail. The following pathogenic genes were evaluated in this study, $\operatorname{Mec} A$, the staphylococcal protein A (spa), which codes for the polymorphic region of protein $A$ (repeat polymorphism of the X-region of the spa gene) and the seven housekeeping genes (arcC, aroE, $g l p F$, gmk, pta, tpi, and yqiL) using the under listed primers (Table 1) and PCR condition (Table 2).

\section{Gel Electrophoresis}

Agarose gel was prepared using 3 grams of agarose gradually dissolved in $200 \mathrm{ml} 1 \mathrm{X}$ tris-acetate EDTA (TAE) (Sigma chemical Ltd.,England) at room temperature. The mixture was then brought to boil at $150^{\circ} \mathrm{C}$ for 2 mins using Microwave heater (HINARI Life Style 800watts model MX310TCSL, UK). Ethidium bromide (8$\mu \mathrm{l})$ (Sigma chemical Ltd., England) was added to stain the amplicons. The PCR products $(10 \mu \mathrm{l})$ were loaded on the gel and run on a Bio-rad electrophorectic machine at 120 $\mathrm{V}$ for $1.5 \mathrm{hrs}$. At the end, the gel bands were viewed using the Bio-rad Gel Doc XR transilluminator Machine.

\section{RESULTS}

Sample Collection and Distribution of Staph. aureus in Poultry Farms in Kano State

A total of 1260 samples were aseptically collected from 
Table 2. Thermocycler Conditions for Antibiotic Resistant and Pathogenic Genes Amplification Among Staph. aureus Isolated from Poultry Farms in Zaria, Nigeria.

\begin{tabular}{ccccccc}
\hline Initial Den. & Den. & Ann. Temp & Extension & No. of circles & Final Ext. & Hold Temp. \\
\hline $94^{\circ} \mathrm{C}$ & $94^{\circ} \mathrm{C}$ & $56^{\circ} \mathrm{C}$ & $72^{\circ} \mathrm{C}$ & $72^{\circ} \mathrm{C}$ & $72^{\circ} \mathrm{C}$ & $10^{\circ} \mathrm{C}$ \\
$5 \mathrm{mins}$ & $30 \mathrm{SeC}$ & $30 \mathrm{Sec}$ & $45 \mathrm{Sec}$ & 36 & $7 \mathrm{mins}$ & $\infty$ \\
\hline
\end{tabular}

Keys: Den. = Denaturation, Ann. Temp. = Annealing temperature, Ext. = Extension.

Table 3. Distribution of Staph. aureus in Poultry Farms in Kano State.

\begin{tabular}{|c|c|c|c|c|c|c|c|c|c|c|}
\hline \multirow[t]{2}{*}{$\mathbf{S} / \mathbf{N}$} & \multicolumn{3}{|c|}{ Sample Collection } & & \multirow{2}{*}{ GS } & \multicolumn{3}{|c|}{ Presumptive Staph. aureus ID } & \multirow{2}{*}{$\begin{array}{c}\text { Agglutina } \\
\text { tion Test }\end{array}$} & \multirow{2}{*}{$\begin{array}{c}\text { Microgene } \\
\text { Kit }\end{array}$} \\
\hline & NSB & CSB & NSW & & & Catalase & DNase & Coagulase & & \\
\hline \multicolumn{11}{|c|}{ Kano central (Farms 1-4) } \\
\hline 1 & 50 & 50 & 5 & NSB & 175 & 175 & 168 & 120 & & \\
\hline 2 & 50 & 50 & 5 & CSB & 170 & 170 & 163 & 160 & & \\
\hline 3 & 50 & 50 & 5 & NSW & 11 & 11 & 9 & 8 & 61 & 19 \\
\hline 4 & 50 & 50 & 5 & Total & 365 & 356 & 240 & 288 & $\begin{array}{l}46 \\
23\end{array}$ & $\begin{array}{c}14 \\
8\end{array}$ \\
\hline \multicolumn{11}{|c|}{ Kano North (Farm $5-8$ ) } \\
\hline 5 & 50 & 50 & 5 & NSB & 160 & 160 & 145 & 100 & & \\
\hline 6 & 50 & 50 & 5 & CSB & 120 & 120 & 80 & 50 & 29 & 12 \\
\hline 7 & 50 & 50 & 5 & NSW & 15 & 15 & 10 & 5 & 20 & 9 \\
\hline 8 & 50 & 50 & 5 & Total & 295 & 295 & 235 & 155 & & \\
\hline \multicolumn{11}{|c|}{ Kano South (Farm $9-12$ ) } \\
\hline 9 & 50 & 50 & 5 & NSB & 190 & 190 & 175 & 90 & $\begin{array}{l}41 \\
35\end{array}$ & $\begin{array}{l}14 \\
10\end{array}$ \\
\hline 10 & 50 & 50 & 5 & CSB & 150 & 130 & 115 & 80 & $\begin{array}{l}35 \\
10\end{array}$ & 10 \\
\hline 11 & 50 & 50 & 5 & NSW & 10 & 10 & 9 & 9 & 19 & 6 \\
\hline 12 & 50 & 50 & 5 & Total & 350 & 330 & 299 & 179 & & \\
\hline Total & 600 & 600 & 60 & 子 1260 & 1010 & 981 & 774 & 622 & 290 & 98 \\
\hline
\end{tabular}

Keys: NSB $=$ Nasal Swab of birds, CSB = Cloacae Swab of birds, NSW = Nasal Swab of Workers, GS = Gram staining, ID = Identification.

Table 4. Distribution of Staph. aureus in Cloacal and Nasal of Poultry Birds and Nasal Swab of Farm Workers Samples in Kano State.

\begin{tabular}{|c|c|c|c|c|c|}
\hline \multirow[b]{2}{*}{ Sample Source } & \multicolumn{3}{|c|}{ Zones in Kano State } & \multirow[b]{2}{*}{ Total } & \multirow{2}{*}{$\begin{array}{c}\text { Percentag } \\
\text { Total }\end{array}$} \\
\hline & $\begin{array}{l}\text { Kano central } \\
\text { (Farms 1-4) }\end{array}$ & $\begin{array}{l}\text { Kano North } \\
\text { (Farm 5-8) }\end{array}$ & $\begin{array}{c}\text { Kano South } \\
\text { (Farm } 9-12)\end{array}$ & & \\
\hline Nasal Swab of birds & 19 & 12 & 14 & 45 & 45.9 \\
\hline Cloacae Swab of birds & 14 & 9 & 6 & 33 & 33.7 \\
\hline Nasal Swab of Workers & 8 & 6 & 6 & 20 & 20.4 \\
\hline Total & 41 & 27 & 26 & 98 & 100 \\
\hline
\end{tabular}

12 farms in Kano State, of which conventional isolation and identification result showed that 562 of the samples had presumptive characteristics of Staph. aureu. Further evaluation using STAPH Agglutination kit reduced the number of the isolates to 290 while on identification using Microgen STAPH kit, $33.8 \%$ (98) of the presumptive isolates were confirmed as Staph. aureus (Table 3). The distribution of Staph. aureus among the sample sources showed that the birds nasal harbored more Staph. aureus $(45.9 \%)$ than the birds cloacal $(33.7 \%)$ and nasal of the farm workers in Kano State (Table 4).

\section{Antibiotics Susceptibility Result}

The antibiotics susceptibility profile of the isolates showed that all the isolates were $(100 \%)$ resistant to Ampicillin and Amoxicillin, 93.3\% to Oxytetracycline, 90\% to Chloramphenicol, $80 \%$ to Erythromycin, $76.7 \%$ to Oxacillin, $63.3 \%$ to Trimethroprim/Sulphamethozaxole, $30 \%$ to Ciprofloxacin and $26.7 \%$ to Gentamicin (Figure 1). The multiple antibiotic resistance index showed that $83.3 \%$ of the isolates had MARI of $>0.3$ and MDR respectively while $16.7 \%$ had MARI of $\leq 0.3$ (Table 5 ). 


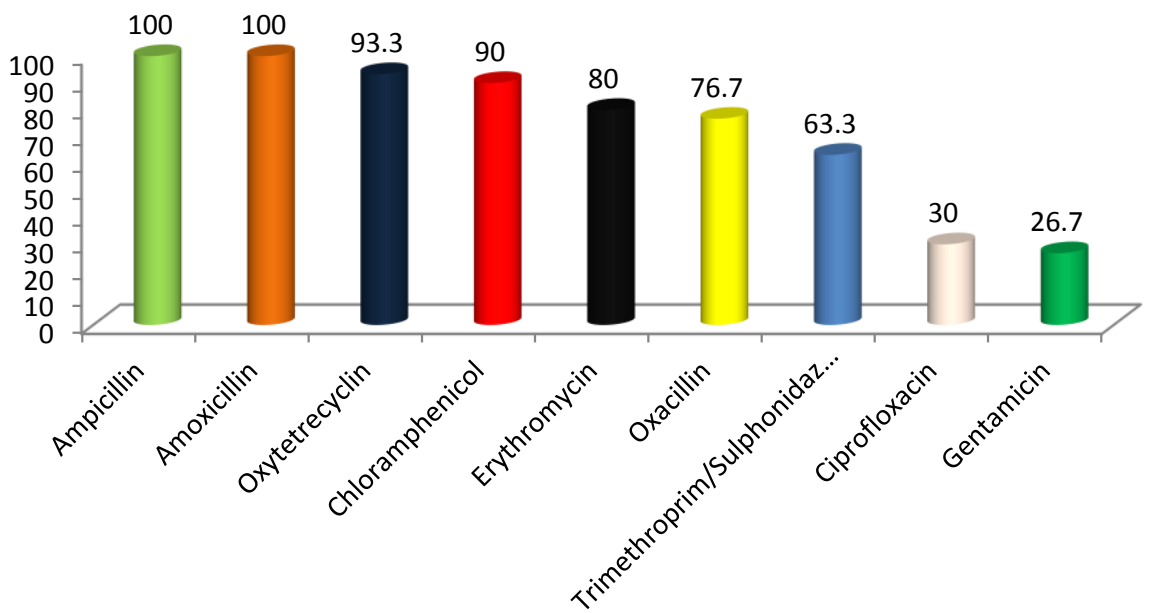

Figure 1. Antibiotics Resistance Profile of Cefoxitin Resistance Staph. aureus from Poultry Farms in Kano State, Nigeria.

Table 5. Antibiotic Resistance Pattern, Classification and MARI of Staph. aureus from Poultry Farms in Kano State, Nigeria.

\begin{tabular}{lclccc}
\hline S/N & Isolate Code & Resistance Pattern & NART & ARC & MARI \\
\hline 1 & $12 \mathrm{C}$ & AMP,AMX,OT, & 3 & Nil & 0.3 \\
2 & $7 \mathrm{~N}$ & AMP,AMX,OT,C,E,OX,SXT & 7 & MDR & 0.7 \\
3 & $83 \mathrm{C}$ & AMP,AMX,OT,C,E,OX,CN, SXT & 8 & MDR & 0.7 \\
4 & $88 \mathrm{~N}$ & AMP,AMX,OT,C,E,OX,SXT & 7 & MDR & 0.7 \\
5 & $3 \mathrm{C}$ & AMP,AMX,OT,C,E,OX,SXT & 7 & MDR & 0.7 \\
6 & $90 \mathrm{C}$ & AMP,AMX,OT,C,E,OX,SXT & 7 & MDR & 0.7 \\
7 & $93 \mathrm{C}$ & AMP,AMX,OT,C,E,OX,CN & 7 & MDR & 0.7 \\
8 & $151 \mathrm{C}$ & AMP,AMX,OT,C,OX,SXT,E & 7 & MDR & 0.7 \\
9 & $67 \mathrm{~N}$ & AMP,AMX,OT,C,OX,E,SXT,CIP,CN & 9 & MDR & 0.9 \\
10 & $73 \mathrm{C}$ & AMP,AMX,OT,C,E,OX,SXT & 7 & MDR & 0.7 \\
11 & $91 \mathrm{~N}$ & AMP,AMX,OT,C,E,OX,SXT & 7 & MDR & 0.7 \\
12 & $86 \mathrm{C}$ & AMP,AMX,OT,C,E,SXT,CIP,CN & 8 & MDR & 0.8 \\
13 & $68 \mathrm{C}$ & AMP,AMX,OT,C,OX,SXT & 6 & MDR & 0.6 \\
14 & $14 \mathrm{C}$ & AMP,AMX,OT,C,E,OX,SXT,CIP & 8 & MDR & 0.8 \\
15 & $12 \mathrm{~N}$ & AMP,AMX,C, & 3 & Nil & 0.3 \\
16 & $39 \mathrm{C}$ & AMP,AMX,OT, E,OX, SXT, C, & 7 & MDR & 0.7 \\
17 & $90 \mathrm{C}$ & AMP,AMX,OT,C,E,OX,CIP,CN & 8 & MDR & 0.8 \\
18 & $76 \mathrm{C}$ & AMP,AMX,OT,C,CIP,E, & 6 & MDR & 0.6 \\
19 & $31 \mathrm{~N}$ & AMP,AMX,OT,C,E,OX,CN & 7 & MDR & 0.7 \\
20 & $145 \mathrm{C}$ & AMP,AMX,OT,C,E,OX,CN & 7 & MDR & 0.7 \\
21 & $69 \mathrm{C}$ & AMP,AMX,C, & 3 & Nil & 0.3 \\
22 & $64 \mathrm{C}$ & AMP,AMX,OT,C,E,OX,SXT,CIP & 8 & MDR & 0.8 \\
23 & $182 \mathrm{C}$ & AMP,AMX,OT,C,OX,SXT,E & 7 & MDR & 0.7 \\
24 & $184 \mathrm{C}$ & AMP,AMX,OT,C,E,SXT,CN,OX & 8 & MDR & 0.8 \\
25 & $95 \mathrm{C}$ & AMP,AMX,OT,C,E,OX,SXT,CIP & 8 & MDR & 0.8 \\
26 & $41 \mathrm{C}$ & AMP,AMX,OT,C,E,OX,SXT & 7 & MDR & 0.7 \\
27 & $35 \mathrm{C}$ & AMP,AMX,OT & 3 & Nil & 0.3 \\
28 & $39 N$ & AMP,AMX,OT, & 3 & Nil & 0.3 \\
29 & $190 \mathrm{~N}$ & AMP,AMX,OT,C,E,OX,CIP, SXT & 7 & MDR & 0.8 \\
30 & $199 \mathrm{C}$ & AMP,AMX,OT,C,E,CIP,OX, & MDR & 0.7 \\
\hline
\end{tabular}

Keys: NART $=$ number of antibiotics resistance to, $\mathrm{ARC}=$ antibiotics resistance classification, $\mathrm{MARI}=$ multiple antibiotics resistance index, MDR = multiple antibiotic resistance. 


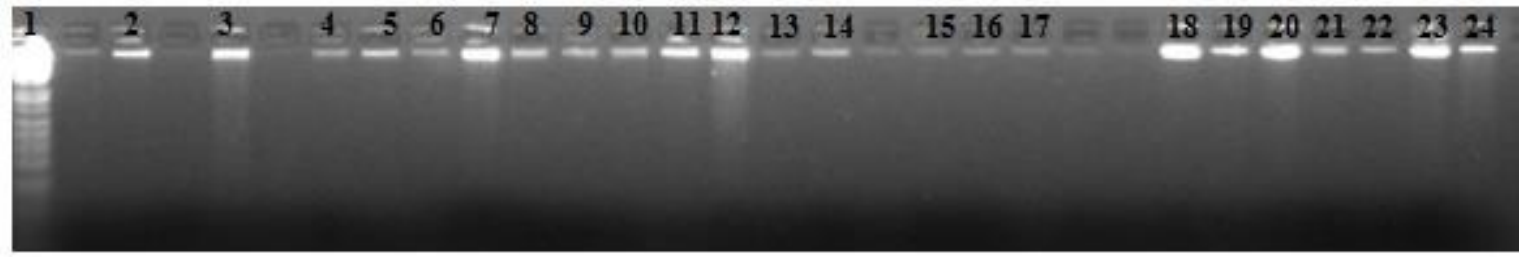

Figure 2. Extraction of DNA from Staph. aureus strains Isolated from Poultry Farms in Kano State.

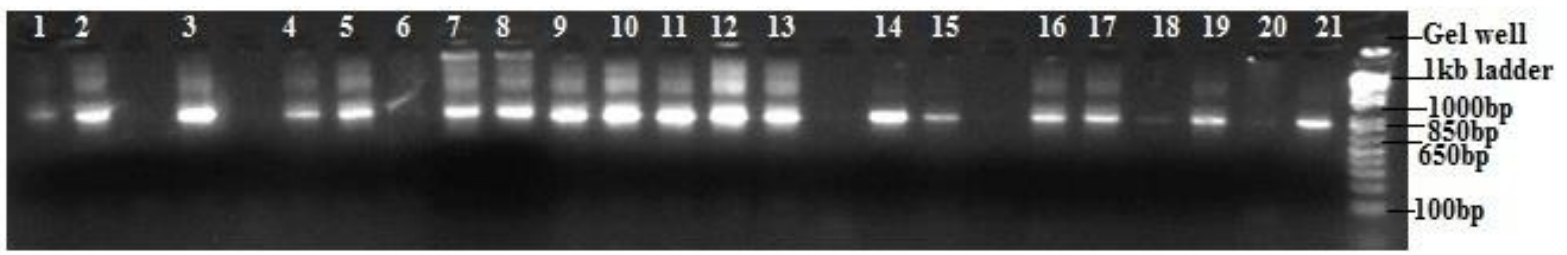

Figure 3. PCR Confirmation of Staph. aureus among Staph. aureus Isolated from Poultry Farms in Kano State using Staph. aureus primer.

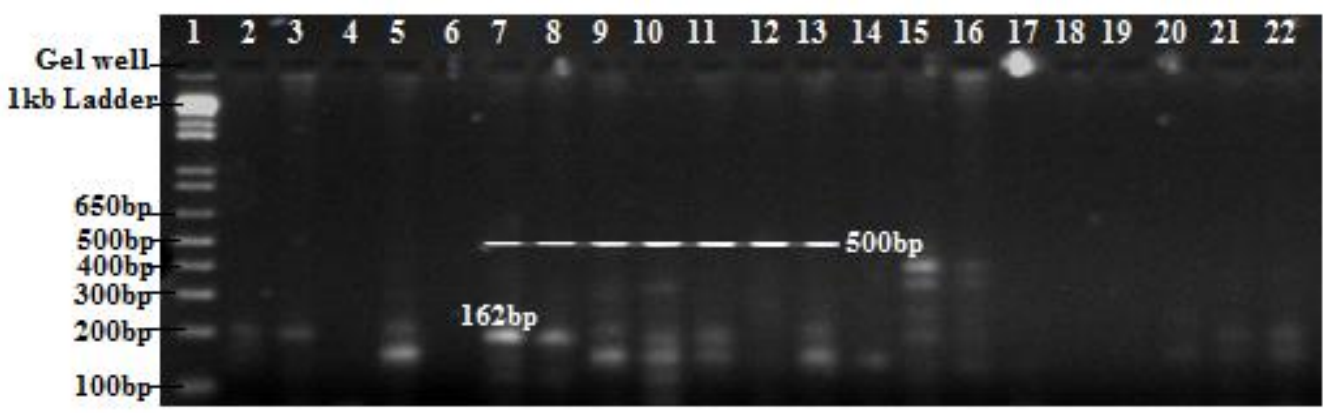

Figure 4. Molecular Characterization of MecA gene (162bp and 500bp respectively) among Staph. aureus Isolated from Poultry Farms in Kano State, Nigeria.

\section{Molecular Analysis}

Genomic DNA was extracted from the Staph. aureus isolates with multiple antibiotic resistance index $\geq 0.7$ (Figure 2). Polymerase chain reaction showed that all the isolates tested were Staph. aureus of $800 \mathrm{bp}$ (Figure 3), $66.7 \%$ of the MDR isolates possess MecA gene (162bp) (Figure 4), while $33.3 \%$ had $M e c A$ of $500 \mathrm{bp}$. Further analysis showed that 3 of the seven housekeeping genes (pta, gmk and yqi) were also present in the MDR isolates at $43.3,20$ and $16.7 \%$ respectively (Figure 5 ) while $10 \%$ express spa typing gene (Figure 6).

\section{DISCUSSION}

Staph. aureus remains one of the predominate health care emerging problem as a result of increase in pathogenicity and emergence of Methicillin-resistant Staphylococcus aureus (MRSA) with multidrug resistance characteristics in hospitals, communities and in poultry (George, 2009; Michael and Robert, 2010; Jhalka et al., 2014). This rising problem calls for periodic surveillance, research and control measures in all areas suspected of Staph. aureus possible contamination especially in food industry (Trish and Emily, 2011). This study observed $33.8 \%(98 / 1260)$ occurrence rate of Staph. aureus from poultry farms and farm workers in Kano State, Nigeria (Table 3). This finding is lower than the report of Suleiman et al., (2013), who reported the occurrence of $83 \%$ Staph. aureus out of 100 tracheal swabs from 100 apparently healthy chickens from small house-holder flocks in Maiduguri, Nigeria, and Mohamed (2013) in Egypt who reported $40.8 \%$ (51/125) occurrence of Staph. Aureus but higher than the report of Neela et al., (2013) who reported $1.4 \%(7 / 503)$ in Malaysia. However, our result substantiates other reports that Staph. aureus could be isolated from animal trachea and nostril. High percentage of the isolates $(30.6 \%)$ were observed to show resistance to cefoxitin; a presumptive identification 


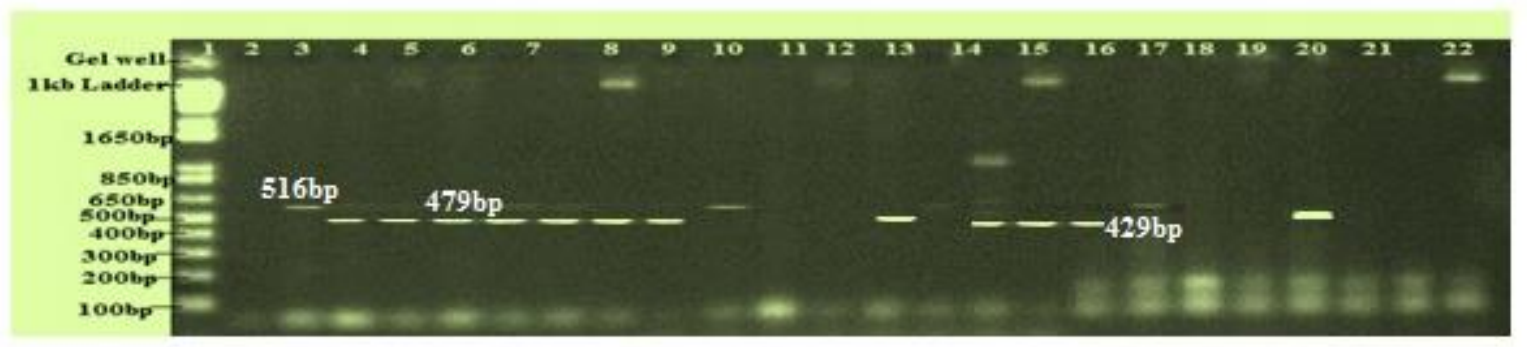

Figure 5. Molecular Characterization of the Seven Housekeeping genes (pta 474bp), gmk (429bp) and yqil (516bp) among Staph. aureus Isolated from Poultry Farms in Kano State.

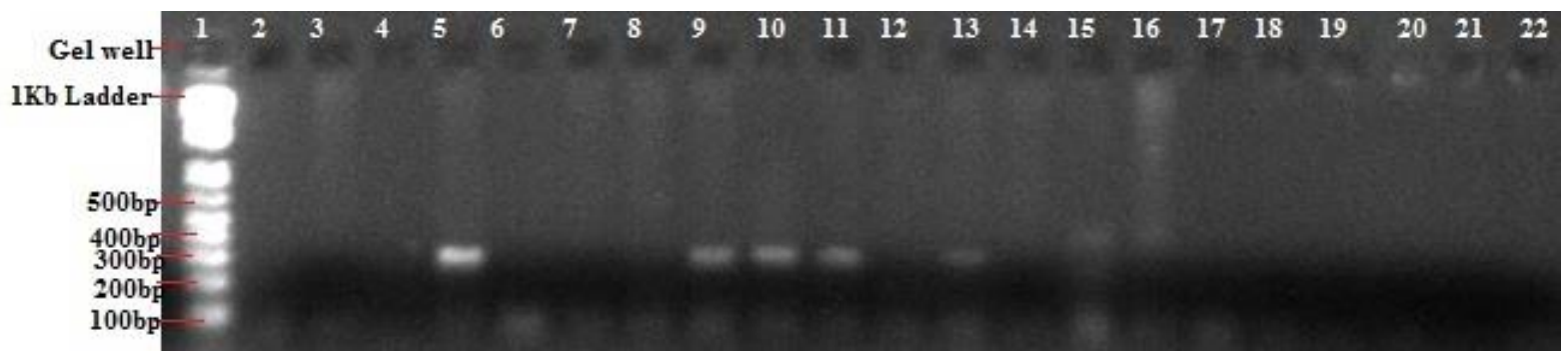

Figure 6. Molecular Characterization of Spa gene (250-637bp) among Staph. aureus Isolated from Poultry Farms in Kano State.

for MRSA in Staph. aureus (Goran and Hong, 2005; Lisa et al., 2006; CLSI, 2013) and subsequently showed varying antibiotics resistance patterns (Table 4) and percentages resistance (Figure 1) from one isolate to another. This finding also concur with the report of Suleiman et al., (2013) who reported that coagulase positive $S$. aureus isolates were susceptible to ciprofloxacin and gentamycin but showed varying degrees of resistance to other antibiotics with most resistance to betalactam (Ampicillin and Amoxicillin). Eighty three point three percent $(83.3 \%)$ of the isolates are MDR and have MARI > 0.3 (Table 4) showing that the isolates have been pre-exposed to antibiotics tested in this study with high multidrug resistance potential. This might be as a result of uncontrolled usage of antibiotics in poultry feeds for growth and diseases. Molecular characterization of mecA gene among these isolates showed that all the MDR isolates were Staph. aureus of 800bp (Figure 2 and 3), 66.7\% of the MDR isolates also possess MecA gene (162bp), while $33.3 \%$ had MecA of $500 \mathrm{bp}$ (Figure 4). These findings concur with the report of Adeyeye and Adewale (2013) in South West Nigeria, who recorded $83.3 \%$ MRSA incidence in poultry attendants, and $95 \%$ in chickens from a poultry farm. MRSA of human-origin has been isolated from raw chicken meat or carcasses in Korea (Lee, 2006) and Japan (Kitai et al., 2005). Although, the pathogenicity of MRSA from different sources varies, those associated with poultry (livestock associated MRSA (LA-MRSA)) rarely cause disease (s). Also there are no known cases of people contracting MRSA from eating meat, if properly prepared $(\mathrm{DH}$, 2013). However, LA-MRSA is a primary occupational risk for those in contact with affected livestock as it has been detected in the air of most barns (7 of $9,77.8 \%$ ), as well as in many samples originating from animals, with detections levels of 50 to $54 \%$ in broiler and 62 to $77 \%$ in turkey farms (Friese et al.,2013).

Reports have also highlighted the possibility of poultry products contamination by MRSA which when in contact with human nasal or skin lesion may lead to colonization and infection. Ingestion of poultry products contaminated with MRSA can cause gastro-intestinal colonization or food poisoning leading to staphylococcal enterotoxinassociated diarrhea and subsequent extra-intestinal infection or transmission (Feßler et al.,2010). Evolutionary analyses on the seven multilocus sequence typing (MLST) genes that encode for proteins of central metabolic functions which can only evolve through mutation and gene replacement, influencing genetic variation and causes phenotypic differences among population genetic (Enright et al., 2000; Lamers et al., 2011) was also carried out on the MDR MRSA to analyze the genetic diversity present in the isolates. The result showed that 3 of the seven housekeeping genes (pta, gmk and yqil) were also present in the MDR isolates at 43.3, 20 and 16.7\% respectively (Figure 5) while 10\% express Spa typing (Figure 6). This implies that overtime, mutation and gene replacement, which influence genetic variation and causes phenotypic differences among population genetic of Staph. aureus had occurred in Kano 
State, which could be the reason behind variation in antibiotic resistance profile expressed among the Staph. aureus. Also, there is a correlation between phenotypic cefoxitin resistance and carriage of $M e c A$ gene.

\section{Conclusion and recommendation}

This study isolated Staph. aureus with high resistance profile to commonly prescribed antibiotics in clinics from poultry farms in Kano State, Nigeria, which might be as a result of antibiotic usage in poultry farms, the presence of $M e c A$ gene and variation in population genetic induced by mutation among the isolated Staph. aureus. This study therefore recommends proper food hygiene and cooking in all abattoir and eateries, which is believed to reduce the risk of infection, transmission of resistance gene and possible colonization. Also strong awareness is advocated in other for consumers to understand the importance of proper handling of poultry products to avoid/reduce cross contamination of MRSA.

\section{CONFLICT OF INTEREST}

The authors declare that they have no conflict of interest.

\section{REFERENCE}

Adelisa L. P., David, H. C., Robert, P. G., Shailen, B., Tonya, S. H., James, S. T., \& William, J. M. (1992). National Nosocomial Infections Surveillance System: MethicillinResistant Staphylococcus aureus in U.S. Hospitals, 19751991. Infection Control and Hospital Epidemiology, 13(10), 582-586.

Adeyeye, J. O., \& Adewale, A. O. (2013). Incidence of Methicillin-Resistant Staphylococcus aureus (MRSA)In a Small Poultry in South West, Nigeria. Journal of Agriculture and Veterinary Science, 5(3), 53-55.

Cheesbrough, M. (2000). District laboratory practice in tropical countries (Part 11). Cambridge, University Press UK. Pp. 134-143.

Cheesbrough, M. (2002). District Laboratory Practice in Tropical countries, Part 2. Cambridge University Press: Pp. 135-159.

Clinical Laboratory Standard Institute (CLSI) (2014). Performance Standards for Antimicrobial Susceptibility Testing; Twenty-Fourth. This document provides updated tables for the Clinical and Laboratory Standards Institute antimicrobial susceptibility testing standards M02-A11, M07A9, and M11-A8. 30(1).

de Lencastre, H., \& Duarte, C. O. (2002) Multiplex PCR Strategy for Rapid Identification of Structural Types and Variants of the mec Element in Methicillin-Resistant Staphylococcus aureus. Antimicrob. Agents Chemother. 46(7), 2155-216.

Department for Environment, Food \& Rural Affairs, Animal Health and Veterinary Laboratories Agency, Department of Health, Public Health England and + others (DH) (2013). Livestock-associated MRSA found at a farm in East Anglia. https://www.gov.uk/government/news/livestock-associatedmrsa-found-at-a-farm-in-east-anglia.
Enright, M. C., Day, N. P., Davies, C. E., Peacock, S. J., Spate, B. G. (2000). Multilocus sequence typing for characterization of methicillin resistant and methicillin susceptible clones of Staph aureus. Journal of Clinical Microbiology, 38(3), 10081015.

Feßler, A., Scott, C., Kadlec, K., Ehricht, R., Monecke, S. and Schwarz, S. (2010) Characterization of methicillin-resistant Staphylococcus aureus ST398 from cases of bovine mastitis. Journal of Antimicrobial Chemotherapy 65, 619-625.

Food and Drug Administration (FDA) (2007). NARMS retail meat annual report, 2007. http://www.fda.gov/downloads/AnimalVeterinary/SafetyHealth /AntimicrobialResistance/NationalAntimicrobialResistanceMo nitoringSystem/UCM166132.pdf. Accessed 29 November 2010.

Friese, A., Schulz, J., Zimmermann, K., Tenhagen, B. A. Fetsch, A., Hartung, J., \& Rösler, U. (2013). Occurrence of Livestock-Associated Methicillin-Resistant Staphylococcus aureus in Turkey and Broiler Barns and Contamination of Air and Soil Surfaces in Their Vicinity.Appl. Environ. Microbiol.79(8), 2759-2766

George, S, Pamela, A. M., Jerome S., Alan, F., Robert, C. M. J., \& George, M. E. (2004). Relationship of MIC and Bactericidal Activity to Efficacy of Vancomycin for Treatment of MethicillinResistant Staphylococcus aureus Bacteremia. J. Clin. Microbiol. 42(6), 2398-2402

George, Y. L. (2009). Molecular Pathogenesis of Staphylococcus aureus Infection. Pediatr Res. 65(5 Pt 2), 71R-77R

Goran, H., \& Hong, F. (2005). Evaluation of Two New Chromogenic Media, CHROMagar MRSA and S. aureus ID, for Identifying Staphylococcus aureus and Screening Methicillin-Resistant S. aureus. J. Clin. Microbiol. 43(8), 42424244.

Harmsen, D. C., Witte, H., Rothganger, W., Turnwald, D. J. (2003). Typing of methicillin-resistant Staph. aureus in a university hospital setting by using novel software for spa repeat determination and data base management. Journal of Clinical Microbiology, 41, 5442-5448.

Igwe, J. C., Onaolapo, J. A., Dauda, E. O., \& Oladipo, H. O. (2013). Plasmid Conjugation in E. coli and Drug Resistance. Nigeria Journal of Biotechnology; 26(1), 41-49

Jhalka, K, Tara, C. S., \& Dipendra, T. (2014). Staphylococcus aureus and Staphylococcal Food-Borne Disease: An Ongoing Challenge in Public Health. BioMed Research International, 2014 (2014), 9.

Kitai, S., Shimizu, A., Kawano, J., Sato, E., Nakano, C., Uji, T., Kitagawa, H. (2005). Characterization of methicillin-resistant Staphylococcus aureus isolated from retail raw chicken meat in Japan. J. Vet. Med. Sci., 67(1),107-110.

Klevens, R. M., Melissa, A. M., Joelle, N., Susan, P., Ken, G., Susan, R., Lee, H. H., Ruth, L., Ghinwa, D., John, M. T., Allen, S. C., Elizabeth, R. Z., Gregory, E. F., Linda, K. M., Roberta, B. C., \& Scott, K. F. (2007). Invasive MethicillinResistant Staphylococcus aureus Infections in the United States. The Journal of the American Medical Association, 298 (15), 1763-1771.

Lamers, R. P., Stinnett, J. W., Muthukrishnan, G., Parkinson, C. L., Cole, A. M. (2011). Evolutionary Analyses of Staphylococcus aureus Identify Genetic Relationships between Nasal Carriage and Clinical Isolates. PLOS ONE, 6(1), e16426. doi: 10.1371/journal.pone.0016426.

Lee, J. H. (2006). Occurrence of methicillin-resistant Staphylococcus aureus strains from cattle and chicken, and 
analyses of their mecA, mecR1 and mecl genes. Vet. Microbiol, 114(1-2), 155-159.

Lisa, L., Deirdre, S., Helen, M., Mary, V., \& Andrew, E. S. (2006). Evaluation of a New Chromogenic Medium, MRSA Select, for Detection of Methicillin-Resistant Staphylococcus aureus. J. Clin. Microbiol., 44(12), 4561-4563.

Ma, X. X., Ito,T., Tiensasitorn, C., Jamklang, M., Chongtrakool, P., Boyle-Vavra, S., Daum, R. S., \& Hiramatsu, K. (2002). Novel type of staphylococcal cassette chromosome mec identified in community-acquired methicillin-resistant Staphylococcus aureus strains. Antimicrob Agents Chemother., 46(4), 1147-1152

Magiorakos, A. P., Srinivasan, A., Carey, R. B., Carmeli, Y., Falagas, M. E., Giske, C. G., Harbarth S., Hindler, J. F., Kahlmeter, G., Olsson-Liljequist, B., Paterson, D. L., Rice, L. B., Stelling, J., Struelens, M. J., Vatopoulos, V, Weber, J. T., \& Monnet, D. L. (2012). Multidrug-resistant, extensively drugresistant and pandrug-resistant bacteria: an international expert proposal for interim standard definitions for acquired resistance. Clinical Microbial Infection, 18, 268-281

Michael, Z. D., \& Robert, S. D. (2010). Community-Associated Methicillin-Resistant Staphylococcus aureus: Epidemiology and Clinical Consequences of an Emerging Epidemic. Clin Microbiol Rev., 23(3), 616-687.

Mohamed, K. (2013). Prevalence of methicillin-resistant Staphylococcus aureus in poultry meat in Qena, Egypt. Veterinary World, 6(10), 711-715

Moran, G. J., Krishnadasan, A., Gorwitz, R. J., Fosheim, G. E., McDougal, L. K., Carey, R. B., \& Talan, D. A. (2006). Methicillin-resistant $S$. aureus infections among patients in the emergency department. N Engl. J. Med., 355(7), 666674.

Naimi, T. S., LeDell, K. H., Como-Sabetti, K., Borchardt, S. M., Boxrud, D. J., Etienne, J., Johnson,S. K., Vandenesch, F., Fridkin, S., O'Boyle, C., Danila, R. N., Lynfield, R., \& Danila, R. N. (2003). Comparison of community-and health careassociated methicillin-resistant Staphylococcus aureus infection. The Journal of the American Medical Association, 290(22), 2976-2984.

Neela, V., Ghaznavi-Rad, E., Ghasemzadeh-Moghaddam, H., Nor-Shamsudin, M., van Belkum, A. \& Karunanidhi, A. (2013). Frequency of methicillin resistant Staphylococcus aureus in the noses of Malaysian chicken farmers and their chicken.Iranian Journal of Veterinary Research, Shiraz University, 14(3), 226-231.
Oliveira, D. C., de Lencastre, H. (2011). Methicillin-Resistance in Staphylococcus aureus is Not Affected by the Overexpression in Trans of the mecA Gene Repressor: A Surprising Observation. PLoS ONE, 6(8), e23287.

Onaolapo, J. A. (2005). Isolation and identification of Staph. aureus from other microbial contaminants using increased salt concentration media. In: Bacterial Genetics Lecture Note. Department of Pharmaceutics and Pharmaceutical Microbiology, Ahmadu Bello University, Zaria. Unpublished.

Paul, S., Bezbarauh, R. L., Roy, M. K., \& Ghosh, A. C. (1997). Multiple antibiotic resistance (MAR) index and its reversion in Pseudomonas aeruginosa. Letters in Applied Microbiology, 24,169- 171.

Sara, E. C., George S., Eli, N. P., Mitchell, J. S., Adolf, W. K., \& Yehuda, C. (2003). Comparison of Mortality Associated with Methicillin-Resistant and Methicillin-Susceptible Staphylococcus aureus Bacteremia: A Meta-analysis. Clin Infect Dis., 36(1), 53-59.

Shopsin, B., Gomez, M., Montgomery, S. O., Smith, D. H., Waddington, M., Dodge, E. E., Bost, A., Riehman, M., Naidich, S., \& Kreiswirth, B. N. (1999). Evaluation of ProteinA Gene Polymorphic Region DNA Sequencing for Typing of Staph. aureus Strains. Journal of Clinical Microbiology, 37(11), 3556356.

Suleiman, A, Zaria, L. T, Grema, H. A., \& Ahmad, P. (2013). Antimicrobial resistant coagulase positive Staphylococcus aureus from chickens in Maiduguri, Nigeria. Sokoto Journal of Veterinary Sciences, 11(1), 51-55.

Trish, M. P., \& Emily, R. M. S. (2011). Hospital Epidemiology and Infection Control in Acute-Care Settings. Clin. Microbiol. Rev., 24(1), 141-173. 